Article

\title{
Energy Recovery from Scrap Tires: A Sustainable Option for Small Islands like Puerto Rico
}

\author{
Eddie N. Laboy-Nieves
}

School of Sciences and Technology, Universidad del Turabo, Box 3030, Gurabo 00778, Puerto Rico; E-Mail: elaboy@suagm.edu; Tel.:+1-787-743-7979 (ext.94264)

Received: 1 April 2014; in revised form: 8 May 2014 / Accepted: 12 May 2014 /

Published: 21 May 2014

\begin{abstract}
Puerto Rico generates and disposes nearly five million/year scrap tires (ST), of which $4.2 \%$ is recycled and $80 \%$ is exported. The Island has one of the world highest electrical service tariff $(\$ 0.28 \mathrm{kWh})$, because of its dependency on fossil fuels for power generation. The Government has not considered ST for electricity production, despite more than 13,000 ST are generated daily, and paradoxically exported for that purpose. Theoretically, if ST recycling increases to $10 \%$ and assuming that the caloric value of ST be $33 \mathrm{MJ} / \mathrm{kg}$, it was estimated that scrap tires processed with pyrolysis can supply annually about $379 \mathrm{MWh}$, a potential value that shall not be unnoticed. This paper is a literature review to describe the legal, technical, and economic framework for the viability of ST for power generation in Puerto Rico using pyrolysis, the most recommended process for ST energy recovery. Data of ST from Puerto Rico was used to model the potential of ST for pyrolytic energy conversion. The herein article is intended to invite other insular countries and territories, to join efforts with the academic and scientific community, and with the energy generation sector, to validate ST as a sustainable option for energy generation.
\end{abstract}

Keywords: efficiency; gasification; islands; Puerto Rico; pyrolysis; scrap tires; sustainable

\section{Introduction}

Energy provision is of utmost importance to the overall sustainability of small islands, given the pervasiveness of energy use, its importance in economic development and living standards, and its impact on the environment [1]. The majority of insular states and territories depends on importation of fossil fuels, or relies on a weak electricity grid connection to the nearest mainland [2]. Therefore, islands are extremely vulnerable by the present inconstancy and unpredictability of the fossils fuel 
market. Consumption of these resources has been growing over the years and is the kernel of economic development, because it inflicts the environment and human health [3]. As a result it is difficult to implement solutions to reduce environmental, social and economic costs so that these islands maintain high quality of life and competitiveness. Energy options also decide other essential aspects for a sustainable island development, which affect competitiveness in key areas, such as tourism, industry, commerce, agriculture, and transportation [4].

Puerto Rico (PR), a commonwealth of the USA, was ranked 31/144 on the 2012 Global Competitiveness Index (GCI) which measures the ability of a country to provide high levels of prosperity, based on twelve core factors, among them the infrastructure [5]. The Island has advanced positively in the last consecutive three years, positioning it as the best economy in Latin America and the Caribbean. The GCI may be accounted as a theoretical indicator that this insular territory is taking strategic actions towards straight governance and innovation, key elements for sustainability. Globally, PR has also been ranked among the first countries with a good provision of paved roads $\left(175.2 \mathrm{~m}^{2} /\right.$ person), with a network length of 26,531 kilometers [6], and a fairly reliable electrical energy grid [5]. As for the 2012 GCI, Puerto Rico ranked third in the availability of scientists and engineers to service the country [5]. The Island is the first Latin American country with a sound collaboration between businesses and universities for research and development, for technological innovation, and for sophistication in production processes [5]. At first glance, anyone may think that with such global ranking, PR is really heading toward a sustainable development. However, contrary to what it is projected by the GCI, the Island is being facing one of its worst economic crisis, because the wearing of the productive structure based on the investment from foreign capital, has hold the generation of wealth [7], the high cost of electrical energy generation that slows the advancement of the economy [8], and the massive consumerism and wasting culture of residents [9]. With regard to electricity, it can be inferred from Figure 1 that there is no apparent relationship between a country's GCI ranking and the cost of its electrical energy for residential and industrial purposes. However, reliable and affordable electricity provision is necessary for not to impose high costs on companies, especially large manufacturing electricity intensive businesses; the Caribbean still lags behind [4].

Emerging states have often experience a lack of harmony in coordinating economic development with environmental management, delaying their aspiration for sustainable development [10]. The present situation of Puerto Rico, especially the cost of electrical energy, may represent the tip of the iceberg, which hides among many elements, an increasingly non-cohesive society, and a lacerated natural environment inflicted by the sprawling of residences, the proliferation of megastores, furtive pollution, and a general poor collective environmental awareness [8]. Despite the reality of a shrinking global and local economy, the majority of Puerto Rico islanders continues in addictive consumerism [8]. This is exemplified among many extravaganzas, by the constant acquisition of new cars, a fact that encourages false states of economic hope and bonanza [11]. Parallel to this erratic social behavior, each year PR imports about 10 million new tires and discards around five million scrap tires [12]. As a result, the Island has been experiencing critical environmental and economic situations, with the increasing accumulation of ST and their clandestine dumping in natural areas. After the banning of the disposal of ST in landfills [12], the government has been paying millions of dollars to private companies that daily collect this material [13]. The adequate management and removal of ST is a relevant issue that urges to be engaged in the equation of Puerto Rico's aspiration toward a sustainable development. 
Figure 1. Comparison of the electrical energy cost (US cents) of several countries ordered according to their GCI (adapted from [4] and [14]).

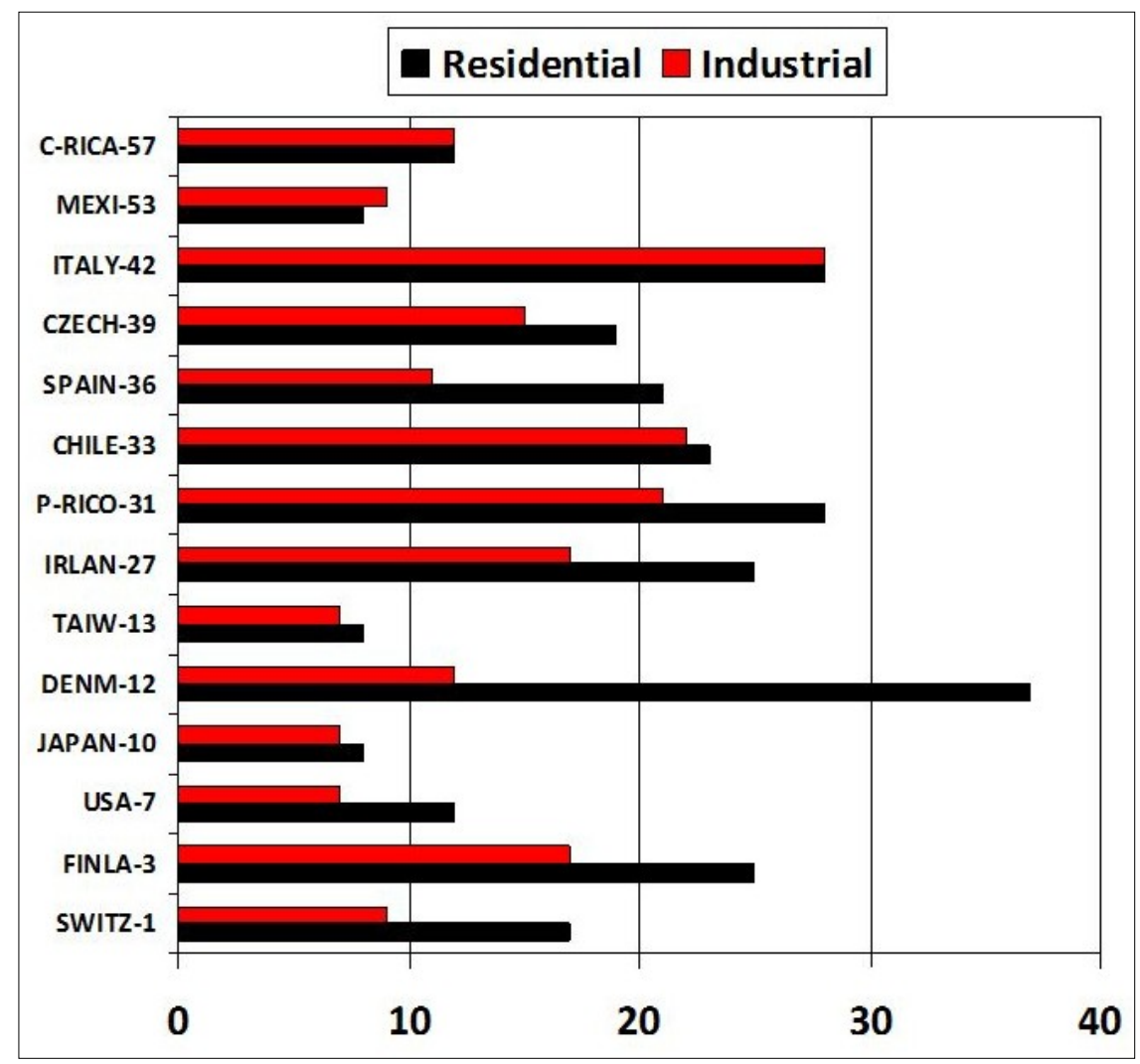

From the public sector, the Environmental Quality Board (EQB) has the ministerial responsibility to apply Act 41, which regulates the use, handling and disposal of ST, and creates incentives for the recycling, and the recovery of energy derived from them. This law allows the development of strategies to ensure a final market and tax benefits for ST [15], and establishes rates for processing and recycling them [16]. The State Public Energy Policy, effective since 1993, stipulates the use of alternative fuels (such as non-toxic solid wastes) to promote an environmentally sustainable development [17]. Being an insular territory of the USA, Puerto Rico has to comply with the regulations of the Environmental Protection Agency (EPA) related to the control of emissions associated with the use of ST for energy recovery. Puerto Rico Act 82, from May 2010, entitles for energy assets diversification, by seeking sustainable and renewable energy resources endemic to the Island, so that the cost of electrical energy be reduced to half the present $\$ 0.28 / \mathrm{kWh}$, one of the highest in the world [14]. It is in this scenario that ST enters to solve two problems with one approach: processing and transforming them into energy, parallel to collecting and eliminating their management and disposal problem on the Island. This option currently has the support of the EPA, after this agency reclassified ST from being a waste to become a fuel resource [18].

The car is the primary method of transport of the majority of the nearly 3.8 million residents of Puerto Rico. This population is largely concentrated in the Metropolitan Area of San Juan, which has an urban train interconnected to a mass transportation system, but with little sponsorship by the locals [19]. As a result, Puerto Rico annually imports about 130,000 cars, equivalent to 617 cars/1000 inhabitants [20]. This wave of cars carries the continuous generation of almost five 
million ST per year [12], which are poorly managed and disposed. Of this total, $\leq 5 \%$ is recycled for leachate control and stabilization material in sanitary landfills [12], but not into energy generation [21]. However, it is shameful that Puerto Rico annually exports to the USA around four millions ST (equivalent to $\sim 40 \times 10^{6} \mathrm{~kg}$ ) for energy recovery [22], while the local provision of energy for injecting the economic activity is not cost-profitable [23].

\section{Caloric Potential of Scrap Tires (ST) and Technologies for Energy Recovery}

Tires contain more than $90 \%$ organic matter and possess the ability to produce excellent calorific fuel [24]. Around 14 and 27 percent of the weight of a $42.4 \mathrm{~kg}$ truck tire corresponds to synthetic and natural rubber, respectively, but this proportion is inverted for a $9.1 \mathrm{~kg}$ car tire [25]. The USA has endorsed the use of shredded (TDF: Tire Derived Fuel) or whole ST as alternate resource to produce electricity [18]. Germany, one of the largest tire manufacturers in the European Union, ranks as the first country with the highest ST treatment for energetic recovery [26]. According to Table 1, the calorific value of tires is comparable to that of coal and crude oil, an attribute that refines the energy recovery potential of ST [27], if the process lessens the impact to the environment and human health [28,29].

Incineration and thermolysis are the most used technologies for processing ST for energy purposes; their modern techniques have significantly reduced the emission of pollutants [30]. Incineration is typically used obtain energy by burning almost any type of solid wastes in ovens from which heat is further applied to generate electricity [31]. However, during the combustion of wastes, $\mathrm{CO}_{2}$ is released and aerosols are contaminated with toxic polyaromatic hydrocarbons (PAH's), heavy metals, dioxins and furans [32]. Incineration recovers less than $40 \%$ of the energy contained in a ST, its emissions require the treatment of slag $(15 \%-20 \%)$ and ashes $(+/-7 \%)$, and the method has very low social acceptance [33].

Table 1. Calorific value of several combustible materials (adapted from [34]).

\begin{tabular}{cc}
\hline Source & $\mathbf{k J} / \mathbf{k g}$ \\
\hline Municipal Wastes & 5800 \\
Mixed Biomass & 15,100 \\
Paper & 17,400 \\
Textiles & 18,600 \\
Bituminous Coal & 26,200 \\
Anthracite & 28,000 \\
Scrap Tires & 31,400 \\
Crude oil & 39,500 \\
\hline
\end{tabular}

Pyrolysis and gasification are processes used to split carbonaceous materials at high temperatures $\left(400-800^{\circ} \mathrm{C}\right.$ ) in the absence of oxygen (pyrolysis), or by a partial oxidation (gasification) sufficient to sustain heat while restricting the oxygen supply [29]. In gasification the majority of carbon and hydrocarbons contained by the solid waste is converted into gaseous products, leaving an inert vitreous slag similar to that of incineration. However, in contrast to incineration that reduces hydrocarbons to basically $\mathrm{CO}_{2}$ and $\mathrm{H}_{2} \mathrm{O}$, gasification leaves a low calorific, but still a combustible substance known as 
syngas [35]. Gasification with plasma arcs, so far in experimental stage, is the most efficient process of energy conversion of ST and its emissions are almost null [35-37].

Pyrolysis is the most recommended alternative for the thermo chemical treatment of ST [38-40]. It produces collateral oils and syngas [40,41], as shown in Figure 2, which an energetic yields from $35 \%$ to $45 \%$, respectively [29,42-47]. The high acceptance of pyrolysis for the treatment of ST is that the derived oils and syngas can be used as fuels or as feedstock for refining crude oil or chemical products $[40,46]$. The best scenarios for the energy conversion of ST by pyrolysis requires a temperature of $430{ }^{\circ} \mathrm{C}$, a constant $0.35 \mathrm{~m}^{3} / \mathrm{h}$ nitrogen flow, and a $10 \mathrm{~mm}$ TDF [47,48]. TDF sizing from 1 to $3 \mathrm{~cm}$ transforms high caloric $\left(68-84 \mathrm{MJ} / \mathrm{m}^{3}\right)$ VOC's into high caloric syngas with very low $\mathrm{CO}, \mathrm{CO}_{2}$, and $\mathrm{H}_{2} \mathrm{~S}$ content [49,50]. When used motor oil [30], sawdust [50], and municipal solid wastes [51] are mixed with TDF during pyrolysis, the caloric value of the resulting syngas increases.

Figure 2. General ST's composition and main products after treatment with pyrolysis (adapted from [52]).

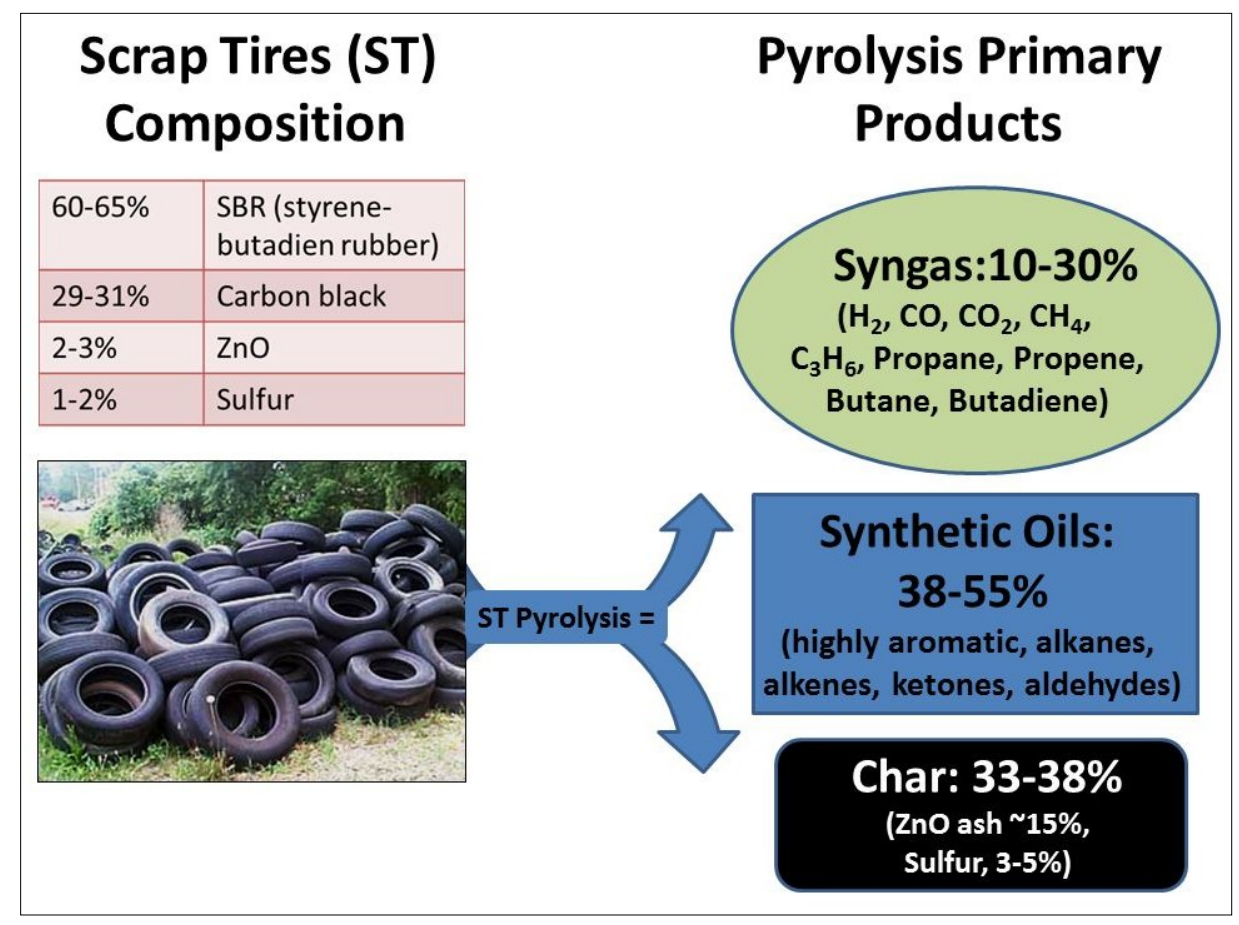

Preheating to initiate exothermic reactions is a modeled strategy that has proved to be significantly more efficient for energy savings in the pyrolysis of ST [44]. Through experimental and simulated tests, it was reported that the energy content of the gaseous phase of the gasification process, increases as the ratio between the mass of the steam and that of scrap tires ("Feeding Ratio, FR") ranges from 0.2 to 1.2 , presenting a peak when $\mathrm{FR}=0.33$ per each kilogram of ST [53]. The gas produced in these tests showed a calorific value of $29.5 \mathrm{~kJ} / \mathrm{kg}$, lacked of nitrogen, and contained $\mathrm{H}_{2}(52.7 \%), \mathrm{CH}_{4}$ (22.2\%), $\mathrm{CO}(18.1 \%)$ and $\mathrm{CO}_{2}(7.0 \%)$, making it an excellent energy source for thermoelectric power and cement production plants [24]. The carbonized solid wastes of ST are chemically modified in situ by post-pyrolysis oxygenation [54]. 


\section{Economic Considerations}

\subsection{Economic Market of ST for Energy Provision in Puerto Rico}

The mass production of tires, and their disposal constrains, constitutes one of the most serious environmental problems of recent years, particularly in island states [55]. The same properties that craft tires as a versatile object, most notably durability and their immunity to biodegradation also make them difficult for disposal and reprocessing [52]. Tires manufacturing requires a high energy consuming process, and after wearing and not properly recycled, ST cause serious environmental pollution problems. ST are vectors of plagues, their dumping impoverishes the landscape, and their chemical components and large size make them recalcitrant for natural degradation [56]. To objectively quantify the environmental costs of processing ST may probably be an endless exercise, given the complexity of n-dimensional factors linked to that issue. However, transforming ST into an energy source, is a double palliative for countries, especially small islands, aiming for sustainable development, but with economies based on fossil fuel importation, inconsistencies in the handling and disposal of this material, and where stealthy dumping is rampant [35], as in Puerto Rico [15] and other Latin American countries [34,57]. To mitigate the adverse economic, environmental and public health effects of the mishandling and disposal of ST, it is crucial to apply the most cost effective techniques headed to recover the energy from this resource $[18,58,59]$.

Puerto Rico generates nearly five million ST per year [12], of which only $4.2 \%$ is recycled or reused [16]. The Island has an on-going installation of noise barriers parallel to main highways, manufactured with approximately 250,000 milled ST [15]. This activity evidences two facts which favor ST reinsertion into the economy: local companies have a secured stock of ST to make a profitable product and, these companies also have the technology to crush scrap tires, which is equivalent to producing Tire Derived Fuel (TDF). Therefore, if Puerto Rico has the capacity to produce TDF, it ought to expand the ST market in order to consider this material as an alternate fuel as done by USA and Germany, two countries with very strict air quality standards, but supporters of the cogeneration of energy using TDF [29]. Despite TDF reduces the cost of energy production [60,61], thermoelectric power plants prefer to use whole ST, since producing TDF can be up to five times more expensive than pulverizing coal [58], while its making consumes large amounts of energy [62]. However, TDF can be used to feed thermal processes in many other industries, for instance metallurgical, cement, pharmaceutical and recycling, or to provide electricity to run the operations of those industries, via energy recovery by pyrolysis, the most recommended method $[39,40]$.

Puerto Rico offers levy benefits for the adequate disposal of ST; the selling tax for new tires covers the cost of its disposal [15]. The handling and disposal fee for every new or used tire imported or manufactured in Puerto Rico is regulated according to their diameter: up to $43 \mathrm{~cm}$ (\$1.65), 44-62 cm (\$7.00), and >62 cm (\$25.00) [16]. The new regulation establishes that the State pays $\$ 0.024, \$ 0.015$ and $\$ 0.049$ for transportation, crushing and export of whole ST, respectively, and $\$ 0.044$ and $\$ 0.024$ for the use of whole or crushed ST, respectively, for energy purposes [16]. Therefore, the Island provides legal protection and economic incentives to use ST for energy conversion and cogeneration projects. 


\subsection{Electrical Energy Production System in Puerto Rico}

Since 1941, electricity in Puerto Rico has been provided by the Puerto Rico Electric Power Authority (PREPA), a public corporation that until May 2010, showcased a strong monopoly [23], and a self-regulated operation without responding to an external controller [63]. For decades, PREPA has exhibited a heavy dependence on fossil fuels to operate an isolated and vertically integrated electric system [64]. As for May 2013, PR has an electrical energy generation capacity of $5665 \mathrm{MWh}$ and its peak generation is around $3685 \mathrm{MWh}$. In 2009, PREPA generated $\$ 4002$ million from the sale of electricity at $\$ 0.22$ and $\$ 0.28 \mathrm{kWh}$, for industrial and residential use, respectively, and allocated $48 \%$ (\$1919 million) of that income to import fuels to feed its five thermoelectric power plants [7,8]. Like on many islands, the cost of providing constant, affordable and reliable electrical energy has been a major obstacle to establish businesses in Puerto Rico $[65,66]$, consequently impeding sustainable development [67]. Even though the burden of a fluctuating and unstable fossil fuels market, PREPA has been very slow in developing new projects with alternative fuels, including the use of solid wastes or scrap tires to cogenerate electrical energy. Although the fact that recent PREPA strategic plans show a diversification of fuels and a reduction in the dependence on oil, as shown in Figure 3, this corporation continues planning long term operations, based on imports of coal and natural gas [63-66]. PREPA aims to reduce the cost of electricity to around $\$ 0.12 \mathrm{kWh}$ by 2013 [8], a goal far to be accomplished, because the price of natural gas co-integrates with the volatile market of oil, weather events, and changes in technology [67]. Hence, PREPA needs to explore the full energy resources spectra available within Puerto Rico, like scrap tires [68], so that the almost $\$ 2$ billion allocated to import fossil fuels, be injected into the local economy and sparks a network of endogenous capital for a more sustainable development $[67,68]$.

Figure 3. Distribution of sources and power (MWh) for electrical energy production in Puerto Rico.

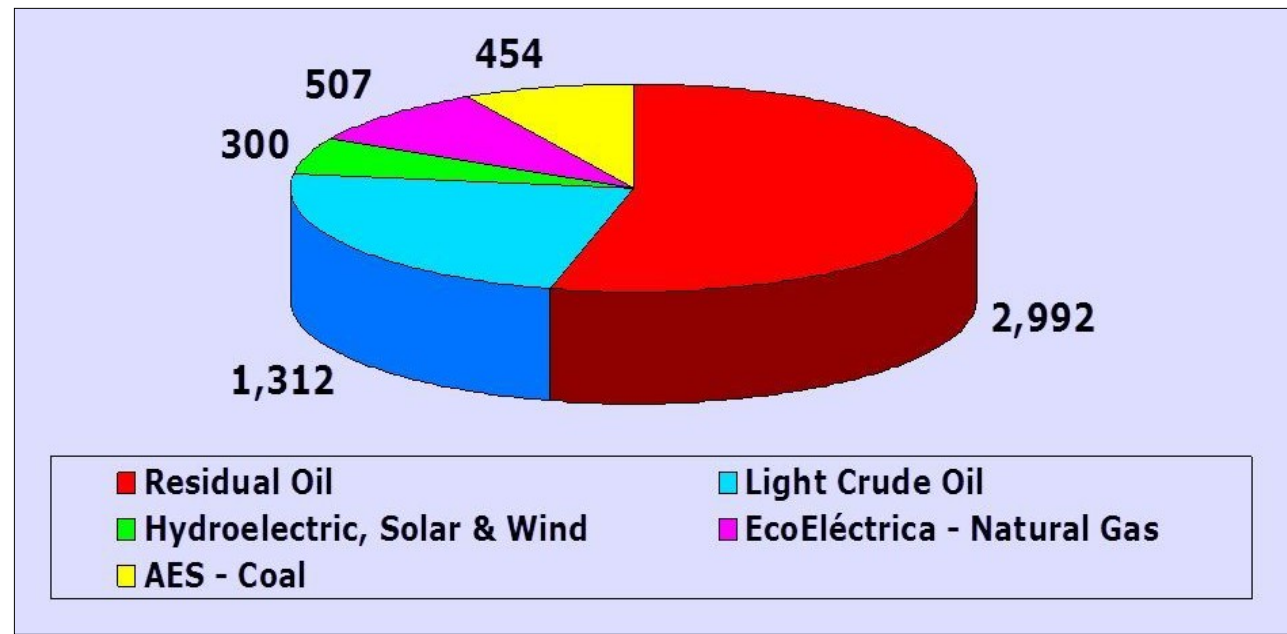

In 1978, the USA Public Utility Regulatory Policies Act (PURPA) approved forced monopolistic electricity providers to buy power from other more efficient producers, if the cost was less than the utility's rate to the consumer. As result, PREPA has welcomed two private initiatives to reduce the Island's dependency on oil for thermoelectric generation [69]. In the Municipality of Peñuelas, the 
$507 \mathrm{MWh}$ natural gas EcoEléctrica became the first independent power producer in the world to integrate a power plant with a liquefied natural gas terminal. With a $\$ 700$ million investment made by its two stockholders, and financing provided by a consortium of 26 international and local banks, EcoEléctrica was able to lower from $99 \%$ to $86 \%$, Puerto Rico's reliance on imported oil [69]. In the Municipality of Guayama, lies the $454 \mathrm{MWh}$ Applied Energy System (AES-PR), a Puerto Rico based company, engaged in electricity generation utilizing low (1\%) sulfur coal imported from Colombia. The company generates electricity in its fluidized bed boilers.

The successful entrance of EcoEléctrica and AES-PR triggered new projects for the cogeneration of electrical energy, but this time using renewable resources. The private sector has installed $101 \mathrm{MWh}$ wind turbines and $97 \mathrm{MWh}$ photovoltaic farms. Two waste to energy facilities ( $90 \mathrm{MWh})$ are in their final permits stage for operation on the Island. Wind, solar and wastes are renewable energy sources in many islands, and the benefits their respective technologies bring to the environment, public health, and the economy have been widely studied [66]. This fact supports the new policy of the Government of Puerto Rico pursuing sustainability, which states that by year 2015, 12\% of all the electrical energy to be generated on the Island must be from renewable sources, a number that should be increased to $15 \%$ by 2020 [68]. However, the slow pace exhibited by PREPA for developing renewable energy pilot projects, reveals the historic weak role of the government to monitor and control that public corporation [69].

It has been reported that ST can be mixed with pulverized coal to power boilers, reducing NOx emissions while increasing the efficiency of energy recovery [61,70]. This option could be applicable for the AES-PR plant, which produces $454 \mathrm{MWh}, \sim 15 \%$ of the electricity consumed on the Island [69]. ST can be integrated to AES-PR for co-firing with coal, as done by the $180 \mathrm{MWh}$ AEE-Hawaii in Oahu, where $\sim 1.4 \times 10^{6} \mathrm{~kg}$ of ST are processed annually, supplying around $1 \%$ of the fuel needed to operate the plant [71]. AES-PR employs $\sim 92,500 \mathrm{~kg} / \mathrm{h}$ of coal to provide $11,300 \mathrm{BTU}(3.31 \mathrm{kWh})$ to start and maintain operational its fluidized bed system (Eng. Ramiro Rivera, AES per. com, January 2013). If AES-PR emulates the use of ST as in AES-Hawaii [71], then integrating the same $1 \%$ of ST, would imply rescuing at least $3.4 \times 10^{6} \mathrm{~kg}$ of ST plus converting them into $4.54 \mathrm{MWh}$ to energize some of the plant operations.

The Strategic Plan of the Puerto Rico Solid Waste Management Authority (ADS) included actions to ensure a final market for ST, giving emphasis to the development and purchase of products derived from such material [72]. The Plan envisions the establishment of two facilities for converting municipal solid waste to energy (WtE), with an estimated processing capacity of $2.6 \times 10^{6} \mathrm{~kg} / \mathrm{day}$; scrap tires were not considered as an energy resource for them [72].

As a result of the ADS WtE goals, two scenarios for processing $445 \times 10^{6} \mathrm{~kg} /$ year of municipal solid wastes in Puerto Rico were modeled using a Thermoselect ${ }^{\odot}$ gasification technology [73]. It was demonstrated that gasification is the preferred strategy for the management of non-recyclable wastes, versus its disposal in landfills [73]. It is within this option where ST must be included on the Island renewable energy resources portfolio, due to its high heat potential, and the new legal framework and economic incentives to develop projects with such purposes [18]. Given that pyrolysis is the best recommended method for the management and energy recovery of ST [39,40], that technique can only renders sound economic benefits if the final products are improved under high standards to reach a marketable yield [26], and if the process reassures not to inflict public and environmental health, the pillars of sustainability. 
Many small islands have cement manufacturing industries. Scrap tires can be integrated as secondary fuels in these industries. It has been proved that ST are an excellent and sustainable energy source, because they can be completely destroyed in the rotary kiln, after exposition to extremely high temperatures, an oxidizing atmosphere, and a relatively long residence time [74]. In Puerto Rico, the multinational company CEMEX has integrated a WtE process that utilizes 5000 to $8000 \mathrm{ST} /$ day to complement coal and used oil for their cement production [69]. This cogeneration strategy represents savings around $\$ 1$ million/year in fuel purchases (Eng. Ramón L. Olivero-Segarra, CEMEX per. com, May 2013). CEMEX industrial facility has a monthly energy consumption of $10 \mathrm{MWh}(\sim \$ 2 \mathrm{million} / \mathrm{month}$ electrical bill) during operating hours. With the proper authorization from federal and local environmental agencies, CEMEX-Ponce would afford annexing to its facilities a small pyrolysis power plant fed with ST to supply part of its energy needs for their rotary furnace. The company is aware that theoretically, the use of ST as a fuel is limited to a maximum of $30 \%$ for the cement industry [74], and that any investment ought to have a short payback period in order to be sustainable.

\subsection{Energy Recovery Potential from ST Processed by Pyrolysis}

Previously, it was stated that Puerto Rico annually generates around five millions ST [12]. The average caloric value reported for ST processed by pyrolysis is $33 \mathrm{MJ} / \mathrm{kg}$ [75], equivalent to $9.17 \mathrm{kWh} / \mathrm{kg}$, but energetic values of 38,37 y $28 \mathrm{MJ} / \mathrm{kg}$, have been respectively reported [29,50,76]. Assuming that a single scrap tire has a mean weight of $10 \mathrm{~kg}$, then it can be inferred that each year Puerto Rico generates $50 \times 10^{6} \mathrm{~kg} \mathrm{ST}(\sim 137,000 \mathrm{~kg} / \mathrm{day})$. From that total, the Island recycles or reuses $4.2 \% \mathrm{ST}$ (5754 kg/day) [16], and exports nearly four millions ST/year [77] equivalent to $40 \times 10^{6} \mathrm{~kg}$. If the former activity is stimulated to process $10 \%$ of the total ST $(13,700 \mathrm{~kg} /$ day), and if the remaining $90 \%$ $(123,300 \mathrm{~kg} /$ day) of ST is not exported, dumped into the environment, or used for other purposes, then ST can be used to feed small scale plants operated by pyrolysis [78] in Puerto Rico. If that amount of tires is assigned for energy conversion, theoretically each day ST can produce 1,130,661 kWh ( 1131 MWh). However, this process has $33.5 \%$ conversion efficiency [29], hence the expected total energy to be produced daily will be around $379 \mathrm{MWh}$. That energy amount represents around 7\% of PREPA's total generation capacity, and it is a firm indicator that ST are a potential endemic and a virtually renewable energy source in Puerto Rico. It has been very profitable for the five local companies that collect, compact and export to the USA, Vietnam and China [77], those four millions ST per year. The ignominious paradox within this scenario is that for decades the island of Puerto Rico has been submitted to an addictive fossils fuel market, supplying billions of dollars to foreign capital interests [67], while ST are in-stock and available for energy conversion. PREPA faces a great opportunity to reassign the relatively high amount of money paid for fossil fuels to promote and develop a native sustainable energy system in which ST can have a key role as an energy source for the Caribbean Region.

Those $379 \mathrm{MWh}$, which can be generated by ST pyrolysis, should not continue to be unnoticed: they truly represent an prevalent renewable energy supply that has the potential to be increased if Puerto Rico becomes a hub for ST from nearby islands, like Trinidad and Tobago and the US Virgin Island, which also export ST to be recycled or integrated to thermal processes [25]. Taking into consideration that PREPA aims to reduce to $\$ 0.12 / \mathrm{kWh}$ the cost of electricity in Puerto Rico, 
then processing ST with a network of small pyrolysis plants hypothetically could mean for PREPA a gross economic injection close to $\$ 45,500 /$ day, plus $\$ 543$ /day $(\$ 0.044 /$ ST State incentive for energy conversion of 12,330 whole ST generated daily), equals $\$ 46,043 /$ day or $\sim \$ 16.8$ million/year from the sale of electricity. These are purely hypothetical results, which assume homogeneity in the caloric value of ST from passenger cars, and a constant ST supply. Estimates do not take into account ST hauling costs, nor the investment and operational costs of a plant based on this type of technology [29]. Results neither considered the range of technical variables related to the performance of ST pyrolysis as reported by many experts in the field $[44,53,61,79-81]$. However, it is worth to mention that within the revenues of the process, the earnings from steel recovery, one of the side products of ST pyrolysis [29,79], were not included. Despite this, with an almost inexhaustible supply of ST in PR and the possibility to receive ST from neighboring Caribbean islands that confront problems with this material [25,82], the herein hypothetical values deserve to be validated by pilot projects through alliances with the local government, PREPA, the private sector, and universities, primarily to compare and examine the $35 \%-45 \%$ performance $[29,42]$, and the different types of pyrolysis techniques [31] that better applies to a tropical island environment. Being pyrolysis the most recommended procedure for processing scrap tire [38-41,44], new models deserve to be developed to characterize its kinetics and to interpret the techniques that will result in obtaining a gas or liquid by-product with high calorific value [54], and to validate that energy recovered exceeds the one required to initiate and sustain the process [53]. Certainly pyrolysis presents marketing reticence due to the high costs of installation of the facilities $[29,76]$, but this factor can be addressed through collaboration networks [70], and the fact that initial costs are recovered in the short-term [29].

\subsection{Pathway to Island Sustainability}

Costs supported for power generation and fuel availability are often a lot higher in islands than in continental areas. Elevated transportation costs, the small scale of energy markets, and the energy generation and distribution systems, put every island in the last step of competitiveness compared with other markets [4]. The human dimensions component of sustainability has become an integral part to achieve the rehabilitation of the environment; the challenge will be to preserve ecosystem functions and to use natural capital while simultaneously sustaining local communities [10]. Renewable energy sources have a significant potential to contribute to the economic, social and environmental factors related to the provision of sustainable energy of small islands, because they improve access to electricity for the majority of the population, and they also reduce emissions of local and global pollutants, while creating socioeconomic development opportunities [83]. To determine whether or not a country is living in a sustainable way, it is recommended the gathering of reliable information of its real welfare, which enables them to protect natural resources more effectively and thereby to improve its socioeconomic development perspective [84].

Puerto Rico is fast becoming a hotbed for sustainable and renewable energy. Through legislation and economic incentives developed and implemented by the Federal and the State Government, companies are being rewarded to establish projects that reduces the Island dependency on fossil fuel, paving the way for a cleaner tomorrow, using renewable energy sources, including scrap tires $[68,69]$. In order to attain a sustainability paradigm in Puerto Rico and other island countries, energy research 
institutions and the energy generation and recovery sectors, need to develop a cognitive network to explore the valorization of scrap tires [68]. Universidad del Turabo's Puerto Rico Energy Center, is willing to lead collaborative projects to study the provision of electricity and thermal energy with the most cost-effective sources, for instance scrap tires, and to examine technologies like pyrolysis, applicable to Caribbean islands [68]. Energy issues of the present generation can be managed with the existing technologies, and almost all the resources to move the world economy onto a sustainability path are already available. The challenge for Puerto Rico and other islands is to cut their dependency on fossils fuels, to harness endemic and cost-effective renewable energy resources, and to promote better management practices to increase the efficiency of power generation and provision.

The exportation of millions of scrap tires from many island countries is equivalent to shipping energy across borders. That practice may make sense in the short term when compared with the cost of landfills in a country without sufficient WtE capacity [85]. However, the economic and the environmental impact of such energy flows make that shipping of energy an unsustainable activity [85]. The time has come for island countries to join efforts for not to mismanage scrap tires, if they are committed to a competitive financial system to support the course of actions towards a sustainable energy ethics.

\section{Conclusions}

The economy of Puerto Rico will continue shrinking in its present recession, mainly because the price of electricity has become a stumbling block to attract new investments, and because the supply of electrical energy seems to continue to be dependent on fossil fuels. The poor management and improper disposal of almost five million scrap tires (ST) generated annually on the Island, have reached negative environmental, economic and social impacts. Through this article, it was demonstrated that the problem can be transformed into an opportunity for ST to become a renewable energy option. The hypothetical model presented in this review, showed that ST are an endemic sustainable energy supply, ideal for the cogeneration of electricity or for its inclusion in thermal processes, and that pyrolysis is the most eco-efficient technology for processing this material. For many decades Puerto Rico has ignored the potential of ST as an energy resource, but paradoxically this material is been exported for such use. Processing ST for energy recovery will mitigate the critical situation of their disposal, while complementing the electrical energy generation portfolio on the Island. Although ST fuels derived from pyrolysis are in beginning stages, they have the potential to be a key alternative renewable resource in island countries. The consolidation of energy options, technological maturity in the exploration of native renewable resources, political willingness, and the intellectual commitment to spark innovation, will place Puerto Rico and many insular countries into a revolutionary scenario. The scientific, academic, public and the private sectors responsible for delineating the pathway for sustainability should join efforts for multidisciplinary small scale projects to encourage the entry of ST into the waste to energy market. Puerto Rico faces a historic moment in which the strength of its alliances will catalyze the elements towards a sustainable development. The Island has no time, nor the physical space for postponing this new feat. A strong symbiotic mutuality from a plethora of sectors will be the keystone for establishing a new energy generation panorama, for the betterment of the Island's economic, social and environmental welfare. 


\section{Acknowledgments}

The author is deeply grateful to engineers Ramón L. Olivero-Segarra, from the CEMEX Puerto Rico Plant, and Ramiro Rivera, from the Applied Energy System Thermoelectric Power Plant, for providing technical information to support this paper.

\section{Conflicts of Interest}

The author declares no conflict of interest.

\section{References}

1. Rosen, M.A. An Enhanced Approach to Energy Economics through the Integration of Exergy and Economics: A Critical Review of Exergy-Based Economic Methods. J. Curr. Issues. Finance Bus. Econ. 2009, 3, 363-428.

2. Duic, N.; Graca, M.; Lerer, M. Increasing the supply of renewable energy sources in island's energy system. Int. J. Sustain. Energ. 2003, 23, 177-186.

3. Gandure, J.; Tunde, M. Biodiesel for Sustainable Energy Provision in Developing Countries. Low Carbon Econ. 2011, 2, 138-143.

4. Zervos, A.; Crettaz, J.; Lins, C. Renewable energy development and its impact on islands. In 100\% RES: A Challenge for Island Sustainable Development; Marín, C., Alves, L.M., Zervos, A., Eds.; UNESCO Center of the Canary Islands: La Palma, Canary Island, Spain, 2005; pp. 19-22.

5. Schwab, K. The Global Competitiveness Report 2011-2012; World Economic Forum: Geneva, Switzerland, 2012.

6. Elvidge, C.D.; Tuttle, B.T.; Sutton, P.C.; Baugh, K.E.; Howard, A.T.; Milesi, C.; Bhaduri, B.L.; Nemani, R. Global Distribution and Density of Constructed Impervious Surfaces. Sensors 2007, 7, 1962-1979.

7. Vélez, G. Perspectivas de la economía de Puerto Rico para el 2010. Available online: http://economiapr.com (accessed on 28 October 2012).

8. Cordero, M. Unidos Trabajando; Boletín de la Autoridad de Energía Eléctrica: San Juan, Puerto Rico, 2010; p. 7. (In Spanish)

9. Laboy-Nieves, E.N. Ética y Sustentabilidad Ambiental en Puerto Rico. In Actas del Foro Internacional de Recursos Hidricos; INDRHI: Santo Domingo, Dominican Republic, 2008; pp. 63-74. (In Spanish)

10. Laboy-Nieves, E.N. Environmental management issues in Jobos Bay, Puerto Rico. In Environmental Management, Sustainable Development and Human Health; Laboy-Nieves, E.N., Schaffner, F., Abdelhadi, A.H., Goosen, M., Eds.; Taylor and Francis: London, UK, 2009; pp. 361-398.

11. Burgos-Alvarado, A.R. Las condiciones para superar la recesión. Boletín Económico del Columbia College 2010, 1, 1-10. (In Spanish) 
12. Autoridad de Desperdicios Sólidos. Reglamento estableciendo el cargo de manejo y disposición de neumáticos y las tarifas para la transportación, procesamiento, exportación, instalaciones de uso final y reciclaje de neumáticos desechados en Puerto Rico; Estado Libre Asociado de Puerto Rico: San Juan, Puerto Rico, 2010. (In Spanish)

13. Pacheco, I. Inundación de gomas a la vista. Available online: http://www.primerahora.com/ inundaciondegomasalavista-662729.html (accessed on 2 January 2013). (In Spanish)

14. International Energy Agency. Energy Prices and Taxes: Third Quarterly Statistics; International Energy Agency Publications: Paris, France, 2010.

15. Botero, J.H.; Valentín, M.O.; Suárez, O.M.; Santos, J.; Acosta, F.J.; Cáceres, A.; Pando, M.A. Gomas trituradas: estado del arte, situación actual y posibles usos como materia prima en Puerto Rico. Revista Internacional de Desastres Naturales, Accidentes e Infraestructura Civil 2005, 5, 69-86. (In Spanish)

16. Autoridad de Desperdicios Sólidos. Reglamento Tarifario para el Manejo y Disposición de Neumáticos. Available online: http://www.ads.gobierno.pr/ neumaticos/Reglamento_Tarifario_ Neumaticos.pdf (accessed on 21 December 2012). (In Spanish)

17. Navarro, A. Política energética: marco legal actual. Presentación del Programa de Colegio. Sea Grant. Universiy of Puerto Rico. Available online: http://uprm.edu/aceer/pdfs/pres_anavarro.pdf (accessed on 21 December 2012). (In Spanish)

18. Environmental Protection Agency. 40 CFR Part 241: Identification of non-hazardous secondary materials that are solid waste. Fed. Regist. 2011, 76, 15456-15551.

19. Padilla, V. Estudio sobre utilización del tren urbano. Publicación de la Vicepresidencia Auxiliar de Investigación Institucional; Sistema Universitario Ana G. Méndez: San Juan, Puerto Rico, 2009. (In Spanish)

20. Rivera-Hernández, Z. Comisión para la Seguridad en el Tránsito. Available online: http://www2.pr.gov/presupuestos/presupuesto2011-2012/Ponencias/CST\%20(Ponencia).pdf (accessed on 18 December 2012). (In Spanish)

21. Miranda, M.L.; Hale, B. Paradise recovered: energy production and waste management in island environments. Energ. Pol. 2005, 33, 1691-1702.

22. Autoridad de Desperdicios Sólidos. Informe Final Sobre la Tasa de Reciclaje y la Tasa de Desvío; Estado Libre Asociado de Puerto Rico: San Juan, Puerto Rico, 2007. (In Spanish)

23. Schaffner, F. Contributions of the energy and environmental sectors to sustainable economic development: A case study from the Caribbean. In Environmental Management, Sustainable Development and Human Health; Laboy-Nieves, E.N., Schaffner, F., Abdelhadi, A.H., Goosen, M., Eds.; Taylor and Francis: London, UK, 2009; pp. 307-337.

24. Manar, E.; Abdul, R.; Nermine, E.; Azim, A. Thermo chemical recycling of mixture of scrap tires and waste lubricating oil into high caloric value products. Energ. Convers. Manag. 2010, 51, 1304-1310.

25. Rubber Manufacturers Association. U.S. Scrap Tire Management Summary. Available online: http://www.rma.org/download/scrap-tires/market-reports/MAR-025-Scrap\%20Tire\%20Market\% 202009.pdf (accessed on 21 October 2013).

26. Samolada, M.; Zabaniotou, A. Potential application of pyrolysis for the effective valorization of the end of life tires in Greece. Environ. Dev.2011, 4, 73-78. 
27. Shah, J.; Jan, M.R.; Mabood, F. Recovery of value-added products from the catalytic pyrolysis of waste tire. Energ. Convers. Manag. 2009, 50, 991-994.

28. Blackman, A.; Palma, A. Scrap tires in Ciudad Juárez and El Paso: Ranking the risks. J. Environ.Dev. 2002, 11, 247-266.

29. University of California Riverside. Technology Evaluation and Economic Analysis of Waste Tire Pyrolysis, Gasification, and Liquefaction; California Integrated Waste Management Board Publication 620-06-004: Riverside, California, USA, 2006.

30. Abdul-Raouf, M.E.; Maysour, N.E.; Abdul-Azim, A.A.; Amin, M.S. Thermochemical recycling of mixture of scrap tyres and waste lubricating oil. Energ. Convers. Manag. 2010, 51, 1304-310.

31. Lam, S.S.; Chase, H.A. A review on waste to energy processes using microwave pyrolysis. Energies 2012, 5, 4209-4232.

32. Conesa, J.; Fullana, A.Y.; Font, R. Tire pyrolysis: Evolution of volatile and semivolatile compounds. Energ. Fuel. 1999, 14, 409-418.

33. Turatsinze, A.; Bonnet, S.; Granju, J.L. Mechanical characterization of cement based mortar incorporating rubber aggregates from recycled worm tires. Build Environ. 2005, 40, 220-226.

34. Cantanhedes, A.; Monge, G. Estado del arte del manejo de llantas en las Américas. Publicación del Centro Panamericano de Ingeniería Sanitaria y Ciencias del Ambiente; World Health Organization: Lima, Peru, 2002. (In Spanish)

35. Huang, H.; Tang, L. Treatment of organic waste using thermal plasma pyrolysis technology. Available online: http://www.aseanenvironment.info/Abstract/41014524.pdf (accessed on 18 December 2012).

36. Layda, J.J. Aprovechamiento energético de residuos: Encuentros empresa Universidad: Colegio oficial de Ingenieros Industriales de Madrid. Available online: http://www.fundacionenergia.es/ PDFs/Biomada\%2006/J.J.Layda.pdf (accessed on 11 October 2012).(In Spanish)

37. Tang, L.; Huang, H.; Zhao, Z.; Wu, C. A preliminary study of plasma pyrolysis of waste tires. Chin. J. Process Eng. 2003, 3, 86-90.

38. Yuan, C.S.; Lin, H.Y.; Wu, C.H.; Liu, M.H. Preparation of sulfurized powered activated carbon from waste tires using an innovative compositive impregnation process. J. Air Waste Manag. Assoc. 2004, 54, 862-870.

39. İlkılıç, C.; Aydin, H. Fuel production from waste vehicle tires by catalytic pyrolysis and its application in a diesel engine. Fuel Process. Tech. 2011, 92, 1129-1135.

40. Karatas, H.; Olgun, H.; Engin, B.; Akgun, F. Experimental results of gasification of waste tire with air in a bubbling fluidized bed gasifier. Fuel 2013, 105, 566-571.

41. Aylon, E.; Murillo, R.; Fernández, A.; Aranda, A. Emission from the combustion of gas phase products at tire pyrolysis. J. Anal. Appl. Pyrol. 2007, 79, 210-214.

42. Xiao, G.; Ni, M.; Chi, Y.; Cen, K. Low-temperature gasification of waste tire in a fluidized bed. Energ. Convers. Manag. 2008, 49, 2078-2082.

43. European Tyre \& Rubber Manufacturers Association, 2011 ed. End of life tyres a valuable resource with a wealth of potential. Available online: http://www.etrma.org/uploads/Modules/ Documentsmanager/brochure-elt-2011-final.pdf (accessed on 11 October 2012).

44. Cheung, K.Y.; Lee, K.L.; Lam, K.L.; Hui, C.W. Integrated kinetics and heat flow modeling to optimise waste tire pyrolysis at different heating rates. Fuel Process. Tech. 2011, 92, 856-863. 
45. Undri, A.; Meini, S.; Rosi, L.; Frediani, M.; Frediani, P. Microwave pyrolysis of polymeric materials: Waste tires treatment and characterization of the value-added products. J. Anal. Appl. Pyrol. Available online: http://dx.doi.org/10.1016/j.jaap.2012.11.011 (accessed on 29 December 2012).

46. Ospina, J.A.; Villada, S. Métodos para caracterizar combustibles líquidos y gaseosos obtenidos de llantas en desuso a través de las normas ASTM. Lámpsakos 2011, 3, 23-31. (In Spanish)

47. Barbooti, M.M.; Mohamed, T.J.; Hussain, A.A.; Abas, F.O. Optimization of pyrolysis conditions. J. Anal. Appl. Pyrol. 2004, 71, 165-170.

48. Lopez, F.A.; Centeno, T.A.; Alguacil, F.J.; Lobato, B. Distillation of granulated scrap tires in a pilot plant. J. Hazard. Mater. 2011, 190, 285-292.

49. Laresgoiti, M.F.; Caballero, B.M.; de Marco, I.; Torres, A.; Cabrero, M.A.; Chomon, M.J. Characterization of the liquid products obtained in tyre pyrolysis. J. Anal. Appl. Pyrol. 2004, 71, 917-934.

50. Cao, Q.; Jin, L.; Bao, W.; Lu, Y. Investigations into the characteristics of oils produced from co-pyrolysis of biomass and tire. Fuel Process. Tech. 2009, 90, 337-342.

51. Galvagno, S.; Casu, S.; Casabianca, T.; Calabres, A. Pyrolysis process for the treatment of scrap tyres: Preliminary experimental results. Waste Manag. 2002, 22, 917-923.

52. Wójtowicz, M.A.; Serio, M.A. Pyrolysis of scrap tires: Can it be profitable? Chemtech 1996, 26, $48-54$.

53. Donatelli, A.; Iovane, P.; Molino, A. High energy syngas production by waste tyres steam gasification in rotary kiln pilot plant: Experimental and numerical investigations. Fuel 2010, 89, 2721-2728.

54. Quek, A.; Balasubramanian, R. Preparation and characterization of low energy post-pyrolysis oxygenated tire char. Chem. Eng. J. 2011, 170, 194-201.

55. Savary, B.; Vincent, R. Used tire recycling to produce granulates: Evaluation of occupational exposure to chemical agents. Ann. Occup. Hyg. 2010, 55, 931-936.

56. Constantinescu, C. Ecological dimension of tire management: Environmental impact of tire use. Int. J. Academic Res.Account. Finance Manag. Sci. 2012, 2, 180-195.

57. Brito E.; Pasquali, C. Comportamientos y actitudes asociados a la disposición de la basura en áreas urbanas no planificadas. Interciencia 2006, 31, 338-344. (In Spanish)

58. Gieré, R.; LaFree, S.T.; Carleton, L.E.; Tishmack, J.K. Environmental impact of energy recovery from waste tires. Geol. Soc. Spec. Publ. 2004, 236, 475-498.

59. Sarkar, S.; Chamberlain, J.F.; Miller, S.A. A comparison of two Methods to conduct material flow analysis on waste tires in a small Island developing state. J. Ind. Ecol. 2011, 15, 300-314.

60. Juma, M.; Koreňová, Z.; Markoš, J.; Annus, J.; Jelemenský, L. Pyrolysis and combustion of scrap tire. Petrol. Coal 2006, 48, 15-26.

61. Talab, I.; Al-Nahari, Z.; Qudaih, R.; Jananjreh, I. Numerical modeling of coal tire-shred co-gasification. Jordan J. Mech. Ind. Eng. 2010, 4, 155-162.

62. Pegg, M.J.; Amyotte, P.R.; Fels, M.; Cumming, C.R.; Poushay, J.C. An assessment of the use of tires as an alternative fuel. Available online: http://www.gov.ns.ca/nse/waste/docs/ TireUsealternativeFuelAssessment.pdf (accessed on 12 October 2012).

63. Marxuach, S.M. Otra mirada al monopolio. El Nuevo Día. Available online: http://www.adendi.com (accessed on 12 October 2012). 
64. Autoridad de Energía Eléctrica. Informe del Oficial Examinador: Vistas públicas sobre el Sistema de Trasbordo de Puerto Rico; Publicación del Estado Libre Asociado de Puerto Rico: San Juan, Puerto Rico, 2010. (In Spanish)

65. Vélez, G. Los costos de tener un sistema energético ineficiente. Available online: http://economiapr.com (accessed on 22 September 2012).

66. Colucci-Ríos, J.A.; O’Neill-Carrasquillo, E.; Irrizarry-Rivera, A.A. Renewable energy in the Caribbean: A case study from Puerto Rico. In Environmental Management, Sustainable Development and Human Health; Laboy-Nieves, E.N., Schaffner, F., Abdelhadi, A.H., Goosen, M., Eds.; Taylor and Francis: London, UK, 2009; pp. 291-305.

67. Mora-Irrizarry, E. Fuentes Energéticas: Luchas comunitarias y medioambiente en Puerto Rico; La Editorial, Universidad de Puerto Rico: San Juan, Puerto Rico, 2012. (In Spanish)

68. Laboy-Nieves, E.N. Neumáticos desechados: ¿Un problema ambiental o una oportunidad energética para Puerto Rico? Revista Dimensión 2011, 25, 15-20. (In Spanish)

69. Misla-Villalba, A.E.; de Jesús-Martínes, J.; Southgate, D. Cartography of Puerto Rico; Publication of the Chamber of Commerce South of Puerto Rico: Ponce, Puerto Rico, 2012.

70. Cano-Serrrano, E.; Cerezo-García L.; Urbina-Freile, M. Valorización material y energética de neumáticos fuera de uso. Informe de Vigilancia Tecnológica; Dirección General de Universidades e Investigación: Madrid, Spain, 2007.

71. Beck, R.W. Integrated Solid Waste Management Plan Update for the City and County of Honolulu; Publication of the Department of Environmental Services, City and County of Honolulu: Hawaii, HI, USA, 2008.

72. Autoridad de Desperdicios Sólidos. Plan Estratégico para el Manejo de Residuos Sólidos en Puerto Rico; Publicación del Estado Libre Asociado de Puerto Rico: San Juan, Puerto Rico, 2004.

73. Balaguer-Dátiz, G.; Krishnan, N. Life cycle comparison of two options for MSW management in Puerto Rico: Thermal treatment vs. modern landfilling. In Proceedings of the 16th North American Waste-to-Energy Conference, Philadelphia, Pennsylvania, USA, 2008; pp. 1-6.

74. De Queiroz-Lamas, W.; Fortes-Palau, J.C.; Rubens-de Camargo, J. Waste materials co-processing in cement industry: Ecological efficiency of waste reuse. Renew. Sustain. Energ. Rev. 2013, 19, 200-207.

75. Singh, S.; Nimmo, W.; Gibbs, B.; Williams, P. Waste tire rubber as a secondary fuel for power plants. Fuel 2009, 88, 2473-2480.

76. Galvagno, S.; Casciaro, G.; Casu, S.; Martino, M. Steam gasification of tyre waste, poplar, and refuse-derived fuel: A comparative analysis. Waste Manag. 2009, 29, 678-689.

77. Autoridad de Desperdicios Sólidos. Mercados y usos de los neumáticos desechados en Puerto Rico. Available online: http://www.ads.gobierno.pr/neumaticos/mercados.htm (accessed on 16 May 2013). (In Spanish)

78. Gerlach, L. Profitability calculation of MINI-05. Available online: http://dgengineering.de/ download/open/Wirtschaftlichkeit-MIDI3-Altreifen-2013.pdf (accessed on 10 May 2014).

79. Corti, A.; Lombardi, L. End life tyres: Alternative final disposal processes compared by LCA. Energy 2004, 29, 2089-2108.

80. Unapumnuk, K.; Keener, T.; Lu, M.; Khang, S. Pyrolysis behavior of tire-derived fuels at different temperatures and heating rates. J. Air Waste Manag. Assoc. 2006, 56, 618-627. 
81. Kř́ž, V.; Brožová, Z.; Přibyl, O.; Sýkorová, I. Possibility of obtaining hydrogen from coal/waste-tyre mixture. Fuel Process. Tech. 2008, 89, 1069-1075.

82. Akyildiz, V.; Özkan, A.; Çokaygil, Z.; Banar, M.; Baydar, S. Improvement of solid product quality in pyrolysis of tyre derived fuels (TDF). Chem. Eng. Trans. 2010, 21, 775-780.

83. Jaramillo-Nieves, L.; Del Río, P. Contribution of renewable energy sources to the sustainable development of islands: An overview of the literature and a research agenda. Sustainability 2010, 2, 783-811.

84. Schlör, H.; Fischer, W.; Hake, J.F.; Laboy-Nieves, E.N. Adjusted genuine savings and Human Development Index: A two dimensional indicator of sustainability. In Environmental and Human Health: Risk Management in Developing Countries; Laboy-Nieves, E.N., Goosen, M., Emmanuel, E., Eds.; Taylor and Francis: London, England, 2010; pp. 73-85.

85. Op den Brouw, A. Turning mixed plastic into fuel. Cogeneration and On-Site Power Production, March-April 2013, pp. 39-41.

(C) 2014 by the author; licensee MDPI, Basel, Switzerland. This article is an open access article distributed under the terms and conditions of the Creative Commons Attribution license (http://creativecommons.org/licenses/by/3.0/). 